\title{
Rapid Diagnosis of Soil Nutrients Using Microscopic Techniques.
}

\author{
Dhananjay Tripathi ${ }^{1}$, M.O Alonso-Pérez ${ }^{2}$ and D. K Tiwari ${ }^{2,3}$
}

1. CSIR-National Environmental Engineering Research Institute (NEERI), Nehru Marg, Nagpur 440020, Maharashtra, India.

2. Catedrático Conacyt, El Colegio de Michoacán, la Piedad, Michoacán, México.

3. Laboratorio de Análisis y Diagnóstico del Patrimonio, El Colegio de Michoacán, la Piedad, Michoacán, México.

The periodic analysis of soil plays important role in nutrient management. Soil nutrient analysis are used to measure soil nutrients that are expected to to be available for plants. Soil analysis, which involve characterization of the soil and its constituents and the composition of the inorganic phases in soils, are broadly termed chemical. A typical chemical analysis involves the identification of the following parameters: $\mathrm{pH}$, redox potential, organic matter content, total nitrogen, calcium carbonate content, available phosphorus, boron, metals $(\mathrm{Cu}, \mathrm{Zn}, \mathrm{Mn}$ and $\mathrm{Fe})$, exchangeable potassium, calcium, magnesium, sodium, anions contents $\left(\mathrm{NO}_{3}{ }^{-}, \mathrm{SO}_{4}{ }^{2-}, \mathrm{PO}_{4}{ }^{3-}, \mathrm{Cl}^{-}\right)$[1]. The above parameters are commonly measured by all soil analysis laboratories and determines soil category and plants to be grown. In a general way the elemental content is determined by inductively coupled plasma atomic emission spectroscopy (ICP-AES), where the samples of soil are previously treated with acids [2]. In this work, the methodology used for analysis of elemental chemical composition of soil is fast and precise. The soil samples were compacted and analysed after drying, milling and homogenization. The method was validated using certified standard reference materials.

The soil analysis was carried out from the fine fraction of the soil $(<2 \mathrm{~mm})$, which was previously subjected to an air drying process at ambient temperature $\left(<40^{\circ} \mathrm{C} \pm 2{ }^{\circ} \mathrm{C}\right)$, which is called "air dry soil". This soil has an optimum moisture content to manipulate and process it, the dry soil mass remains constant and the microbial activity is low during storage. A tablet was obtained for soil fine fraction analysis, which was done using SEM-EDS (Scanning electron microscope Jeol-JSM-6390LV / LGS, with a dispersive energy system model LK-IE250 Oxford Inca Energy 250) and FRX (Ray fluorescence X, portable model Thermo Scientific Niton XL3t), in order to obtain the elemental chemical composition of the soil of the insoluble / solid fraction. For the analysis of the soluble / liquid fraction; from the dry soil to the air was made a dilution with distilled water $(1: 2)$, followed by a stirring process for 30 minutes and a rest of one hour. After the resting time elapsed, $\mathrm{pH}$, electrical conductivity, and oxide-reduction potential were determined with a Thermo Scientific Orion Star A211 potentiometer. Followed by a rest period of 24 hours, and from which the parameters mentioned above were read again. In addition to these analyses, moisture, organic matter by the Walkley \& Black method, textural class (hydrometric method), bulk density and granulometry were determined by conventional methods [3].

Table 1, shows the results obtained from a soil sample prepared for the growth of corn cultivation in optimum condition together with reference soil (standard), which proves the validity of our methodology as well the soil condition for the planned crop. 
[1] A.L Page, RH. Miller and D.R Keeney, American Society of Agronomy, Inc. Soil Science Society of America, Inc. Madison, Wisconsin, USA (1982)

[2] J.A Baldok, J.O Skjemstad, Soil organic carbon/soil organic matter. In Soil analysis: an interpretation manual, (1999), p. 159-170.

[3] P. Hazelton, B. Murphy, Interpreting Soil Test Results. What do all the numbers mean?, Department of Natural Resources, CSIRO Publishing (2007)

Table 1.Comparison of analytical results of the main elements (\%) in reference soils and soil for agricultural use.

\begin{tabular}{|l|l|c|c|c|c|}
\hline \multirow{2}{*}{\multicolumn{2}{|c|}{ ELEMENT, $[$ OXIDE] $]$}} & \multicolumn{2}{c|}{ REFERENCE SOIL } & \multicolumn{2}{c|}{ TASTED SOIL } \\
\cline { 3 - 6 } \multicolumn{2}{l|}{} & $\begin{array}{c}\text { ELEMENT } \\
(\%)\end{array}$ & $\begin{array}{c}\text { OXIDE } \\
(\%)\end{array}$ & $\begin{array}{c}\text { ELEMENT } \\
(\%)\end{array}$ & $\begin{array}{c}\text { OXIDE } \\
(\%)\end{array}$ \\
\hline SILICON & $\mathrm{Si},\left[\mathrm{SiO}_{2}\right]$ & 22.521 & 48.18 & 20.653 & 44.186 \\
\hline ALUMINIUM & $\begin{array}{l}\mathrm{Al}, \\
{\left[\mathrm{Al}_{2} \mathrm{O}_{3}\right]}\end{array}$ & 5.067 & 9.574 & 6.753 & 12.760 \\
\hline TITANIUM & $\mathrm{Ti},\left[\mathrm{TiO}_{2}\right]$ & 0.282 & 0.471 & 0.143 & 0.240 \\
\hline CARBON & $\mathrm{C},[\mathrm{C}]$ & 9.994 & 9.994 & 12.063 & 12.060 \\
\hline OXYGEN & $\mathrm{O},[\mathrm{O}]$ & 50.67 & 50.67 & 53.633 & 53.636 \\
\hline NITROGEN & $\mathrm{N},\left[\mathrm{NH}_{3}\right]$ & 0.282 & 0.343 & 0.110 & 0.135 \\
\hline PHOSPHORUS & $\mathrm{P},\left[\mathrm{P}_{2} \mathrm{O}_{5}\right]$ & 0.31 & 0.71 & 0.073 & 0.168 \\
\hline POTASSIUM & $\mathrm{K},\left[\mathrm{K}_{2} \mathrm{O}\right]$ & 1.69 & 2.036 & 0.470 & 0.562 \\
\hline CALCIUM & $\mathrm{Ca},[\mathrm{CaO}]$ & 1.69 & 2.365 & 0.747 & 1.047 \\
\hline MAGNESIUM & $\begin{array}{l}\mathrm{Mg}, \\
{[\mathrm{MgO}]}\end{array}$ & 1.268 & 2.103 & 0.520 & 0.859 \\
\hline SULFUR & $\mathrm{S},[\mathrm{S}]$ & 0.04 & 0.04 & 0.020 & 0.023 \\
\hline SODIUM & $\begin{array}{l}\mathrm{Na}, \\
{\left[\mathrm{Na}{ }_{2} \mathrm{O}\right]}\end{array}$ & 1.07 & 1.442 & 0.253 & 0.343 \\
\hline IRON & $\begin{array}{l}\mathrm{Fe}, \\
{\left[\mathrm{Fe} \mathrm{O}_{3}\right]}\end{array}$ & 5.067 & 7.245 & 3.270 & 4.676 \\
\hline MANGANESE & $\begin{array}{l}\mathrm{Mn}, \\
{[\mathrm{MnO}]}\end{array}$ & 0.071 & 0.092 & 0.090 & 0.116 \\
\hline ZINC & $\mathrm{Zn}[\mathrm{ZnO}]$ & 0.011 & 0.014 & 0.007 & 0.008 \\
\hline CHLORINE & $\mathrm{Cl}$ & 0.011 & 0.011 & $\mathbf{N D}$ & \\
\hline
\end{tabular}

*ND, Not detected 